\title{
Effect of the concentration of inoculum and tensoactive on the efficiency of Bipolaris sorokiniana infection in wheat leaves
}

\author{
Erlei Melo Reis ${ }^{1}$, Tiago Zanatta \& Anderson L. Danelli
}

Universidade de Passo Fundo, Faculdade de Agronomia e Medicina Veterinária Passo Fundo, RS. ${ }^{1}$ Fellow of CNPq. Autor para correspondência: Erlei Melo Reis (erleireis@upf.br)

Data de chegada: 25/02/2013. Aceito para publicação em: 23/05/2014.

$10.1590 / 0100-5405 / 1869$

\section{ABSTRACT}

Reis, E. M.; Zanatta, T.; Danelli, A.D. Effect of the concentration of inoculum and tensoactive on the efficiency of Bipolaris sorokiniana infection in wheat leaves. Summa Phytopathologica, v.40, n.2, p.178-181, 2014.

Techniques that result in increased pathogen infection rates by employing reduced quantities of fungal spores with sparse sporulation have been developed. Experiments under controlled environment conditions were conducted to evaluate the effect of the density of Bipolaris sorokiniana conidia on the intensity of wheat helminthosporiosis. Using a selected inoculum density, the concentration of the tensoactive (Tween 20) that promoted maximum infection by the causal agent of the disease was determined. The density of lesions and the estimated severity of the disease were quantified. The selected inoculum density was $1.5 \times 10^{4}$ spores. $\mathrm{mL}^{-1}$ plus $480 \mu \mathrm{L}$ tensoactive. $\mathrm{L}^{-1}$ water, resulting in a disease severity that allows selecting wheat cultivars resistant to $B$. sorokiniana.

Additional keywords: Inoculum density, helminthosporiosis, Triticum aestivum.

\section{RESUMO}

Reis, E. M.; Zanatta, T.; Danelli, A.D. Efeito da concentração de inóculo e de tensoativo na eficiência de infecção de Bipolaris sorokiniana, em folhas do trigo. Summa Phytopathologica, v.40, n.2, p.178-181, 2014.

Técnicas que resultam em aumento da taxa de infecção do patógeno a partir de quantidades reduzidas de esporos de fungos com esporulação escassa, têm sido desenvolvidas. Em experimentos conduzidos sob condições de ambiente controladas avaliou-se o efeito da densidade de conídios de Bipolaris sorokiniana sobre a intensidade da helmintosporiose do trigo. Com uma densidade de inóculo selecionada determinou-se a concentração de tensoativo (Tween 20) que promoveu a máxima infecção do agente causal da doença. Quantificou-se a densidade de lesões e a severidade estimada da doença. A densidade de inóculo selecioanda foi a de $1,5 \times 10^{4}$ esporos. $\mathrm{mL}^{-1}$ acrescida de $480 \mu \mathrm{L}$ do tensoativo. $\mathrm{L}^{-1}$ de água, resultando numa severidade da doença que permite selecionar cultivares de trigo com resistência à $B$. sorokiniana.

Palavras-chave adicionais: Densidade de inóculo, helmintosporiose, Triticum aestivum.

One of the main limits to wheat production in Brazil is the occurrence and the severity of diseases caused by fungi, bacteria and viruses (6).

Leaf diseases show high occurrence frequency and damage range, and among them are leaf spots caused by Bipolaris sorokiniana (Sacc.) Shoem., Drechslera tritici-repentis (Died) Shoem., and Stagonospora nodorum and (Berk) Berk. (6). Damage caused by leaf spots may reach $80 \%$ (4) and can be assessed by using the damage equation $y=1,000$ - $5.9 \mathrm{I}$ (where $\mathrm{y}$ is the wheat yield normalized to $1,000 \mathrm{~kg} \cdot \mathrm{ha}^{-1}$ and I is the leaf incidence) for final tillering stage (6).

The aims of this study were (i) to identify the density of inocula reproducing under controlled conditions and the intensity of leaf spot under conditions similar to field conditions; and (ii) to determine the adjuvant concentration that promotes the maximum efficiency of $B$. sorokiniana infection in wheat, to be used in the screening of wheat germplasm resistance.
The experiments were conducted in a growth chamber built in masonry and containing equipment for temperature and photoperiod control.

In the first step of the study, an inoculum density resulting in maximum intensity of the disease infection without lesion coalescence on the host leaves was selected. Treatments consisted of the following conidium concentrations: $0,2.5 \times 10^{3}, 5.0 \times 10^{3}, 1.0 \times 10^{3}, 1.5 \times 10^{5}, 2.0$ $\mathrm{x} 10^{5}$ and $2.5 \times 10^{5} . \mathrm{mL}^{-1}$ water. To improve leaf wetness, a tensoactivebased polioxyethylene sorbitane monolaurate (Tween 20 - Synth) at $60 \mu \mathrm{L} . \mathrm{L}^{-1}$ of water was used.

The fungal inoculum was obtained by isolating $B$. sorokiniana from wheat leaf spot. Monosporic isolation was done by maintaining pure colonies by repeated transfers and increased inocula in potato sucrose agar substrate (3).

The largely grown and susceptible wheat cultivars 'BR 23' and 'Fundacep Cristalino' were grown in pots containing $1.0 \mathrm{~kg}$ substrate 

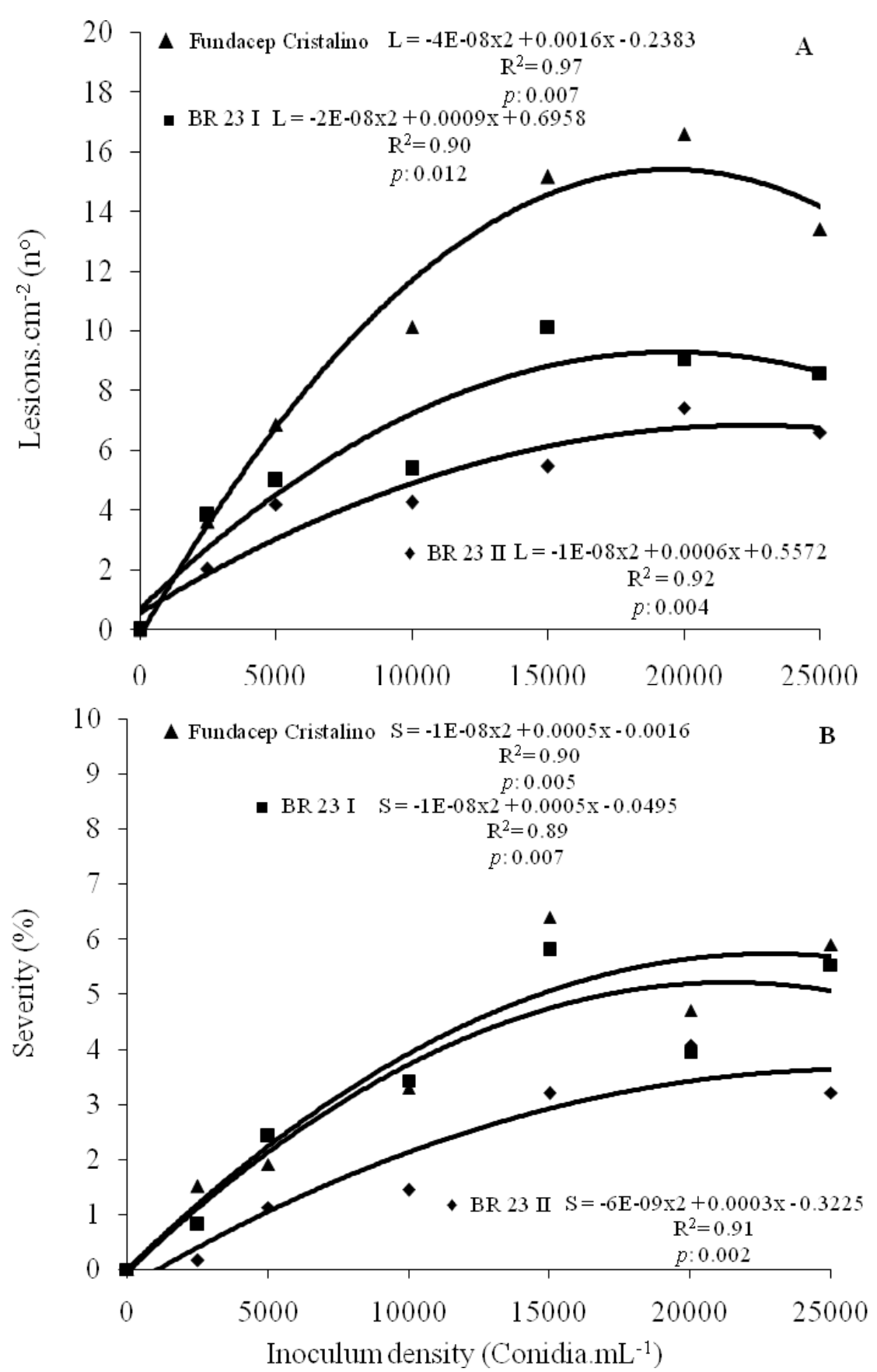

Figure 1. Relationship of Bipolaris sorokiniana inoculum density to the number of lesions $/ \mathrm{cm}^{2}(\mathrm{~L})(\mathrm{A})$ and to the estimated severity $(\mathrm{S})(\mathrm{B})$ of wheat helminthosporiosis for two cultivars, maintaining the tensoactive (Tween 20 ) at $60 \mu \mathrm{L} / \mathrm{L}$ water.

and inoculated at the growth stage 14, when they showed four expanded leaves (11). A hand sprayer was used to inoculate the spore suspension at a quantity sufficient to prevent unprotected areas, which may compromise the reliability of results. Then, the plants were kept in a moist chamber for 28 hours at $23^{\circ} \mathrm{C}$ and allowed to grow $(5,7)$ under $12 \mathrm{~h}$ photoperiod provided by fluorescent light bulbs maintained at $5 \mathrm{~cm}$ above the plants. At seven days after inoculation, the disease intensity was assessed by counting the number of lesions. $\mathrm{cm}^{-2}$, and the severity was rated according to a visual grade scale.

The experiment using wheat 'BR23' was repeated twice (Figure 2, I and II) and that using 'Fundacep Cristalino' was repeated once.
The tensoactive concentration of $60 \mu \mathrm{L} . \mathrm{L}^{-1}$ water used in the first step of this study did not provide complete and uniform wetting of wheat leaf blades. Therefore, in the second phase, we identified the adjuvant concentration in the infectious process by optimizing leaf wetness. The following concentrations: $0,30,40,120,180,240,300$ and $600 \mu \mathrm{L} . \mathrm{L}^{-1}$ water were tested, as well as $B$. sorokiniana inoculum density fixation at $1.0 \times 10^{4}$ conidia. $\mathrm{mL}^{-1}$.

A randomized experimental design was adopted, including eight treatments and four replicates. Data underwent analysis of variance, and when there was significance regression analysis was performed.

Studies aimed at achieving reproducible and standardized data 


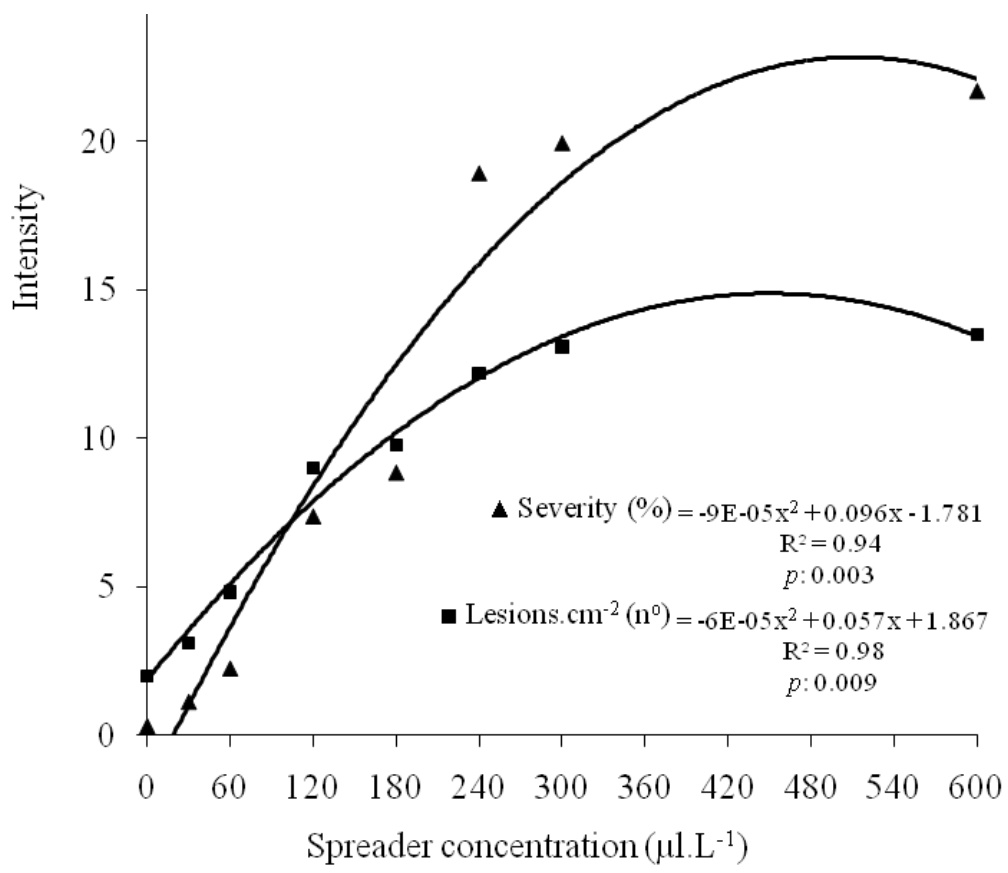

Figure 2. Relationship of polioxyethylene sorbitane monolaurate (Tween 20 ) concentrations to the estimated severity $(\mathrm{S})$ and to the number of leaf lesions/cm ${ }^{2}$ (L) of wheat helminthosporiosis by fixing a concentration of 10,000 conidia $/ \mathrm{mL}$.

in artificial inoculations require the inoculum concentration and its infective potential (2). The relationship between inoculum density and leaf spot intensity was represented by quadratic polynomial equation (Figure 1). The number of lesions. $\mathrm{cm}^{-2}$ and the estimated leaf spot severity increased with increasing concentrations of $B$. sorokiniana inocula (Figure 1). In the experiments, inoculation with uredospore concentrations above $1.5 \times 10^{3} \cdot \mathrm{mL}^{-1}$ generated excessive disease intensity, impairing its quantification and indicating early leaf senescence.

In all three experiments, the disease showed increased intensity quantified from 5.48 to 15.0 lesions. $\mathrm{cm}^{-2}$ and severity from 3.2 to $6.4 \%$. However, there was rapid lesion coalescence. On the tenth day after inoculation, premature leaf senescence started, which was an undesirable effect. Such factors usually occur in studies conducted under environments showing temperatures between 23 and $30^{\circ} \mathrm{C}$, highly conducive to the development and the formation of a large number of necrotic lesions for this pathosystem (5).

Similar results were found by Toledo et al. (9), who related the density of $B$. sorokiniana inocula to the intensity of brown spot in barley (Hordeum vulgare L.). The greatest density of spots per leaf and severity of barley brown spot were obtained with $1.4 \times 10^{3}$ and $1.65 \times 10^{3}$ conidia. $\mathrm{mL}^{-1}$, decreasing thereafter. Those concentrations led to 182 spots per leaf or $79 \%$ severity, respectively.

The values of inoculum density obtained in this experiment and by Toledo et al. (9) may be useful in selecting tolerant/resistant cultivars in plant breeding programs, since in some cases susceptible/resistant cultivars cannot be differentiated at low intensity, and differences cannot be identified between lines/cultivars at very high concentrations (1).

Furthermore, concentrations from $5.0 \times 10^{3}$ to $1.0 \times 10^{4}$ conidia. $\mathrm{mL}^{-1}$ can be useful in studies in which the leaves must be kept viable for a long period.

The surface of wheat leaves is hydrophobic, which makes difficult their wetting by nonpolar compounds (10). The adjuvant tensoactive substance, or spreader, reduces the surface tension, causing the flattening of droplets and increasing their contact with the leaf surface
(8).

A tensoactive improves the performance of pesticides. The water molecule has a high surface tension and this leads to the formation of water droplets when sprayed on a waxy surface. A spray drop must be able to wet the foliage and spread out or cover a leaf area for the pesticide to perform its best leaf control function. The tensoactive acts by reducing the water surface tension on the surface of the sprayed drop and by reducing the interfacial tension between the drop and the surface (8).

Increased disease intensities were expressed by two pathometric methods (Figure 1) used only in response to the tensoactive concentration. The relationship between the tensoactive concentration and the wheat leaf spot intensity was represented by quadratic polynomials (Figure 2). The highest density of lesions was achieved by adding $480 \mu \mathrm{L}$ of tensoactive. $\mathrm{L}^{-1}$ water (Figure 2). However, concentrations higher than $240 \mu \mathrm{L}$ of tensoactive. $\mathrm{L}^{-1}$ water resulted in plant lodging, an undesirable factor. Therefore, a maximum of $240 \mu \mathrm{L}$ tensoactive. $\mathrm{L}^{-1}$ water is suggested for screening of resistant cultivars/lines in wheat inoculation.

The intensity of wheat brown spot caused by $B$. sorokiniana can be increased by the inoculum density $\left(1.5 \times 10^{4}\right.$ spores. $\left.\mathrm{mL}^{-1}\right)$ and/or the tensoactive concentration $\left(480 \mu \mathrm{L}^{\mathrm{L}} \mathrm{L}^{-1}\right.$ water $)$ in artificial inoculation under controlled environment $\left(23^{\circ} \mathrm{C}\right.$ and $12 \mathrm{~h}$ fotoperiod).

\section{REFERENCES}

1. Carvalho, L.P., Carvalho, J.M.F.C., Lima, E.F.; Cavalcante, F.B. Influência da concentração de esporos na patogenicidade de Colletotrichum gossypii South var. cephalosporioides A.S. Costa e avaliação da resistência de cultivares e linhagens de algodoeiro herbáceo à ramulose. Fitopatologia Brasileira, Brasília, DF, v. 6: 395-402, 1981.

2. Fernandes, C.D., Del Peloso, M.C., Maffia, L.A., do Valle, F.X.R. ; Zambolim, L. Influência da concentração de inóculo de Cercospora coffeicola e do período de molhamento foliar na intensidade da cer- 
cosporiose do cafeeiro. Fitopatologia Brasileira, Brasília, DF, v. 16:39-43, 1991.

3. Fernandes, M. R. Manual para laboratório de fitopatologia. Passo Fundo, EMBRAPA-CNPT, 1993. 128p (Documentos, 6).

4. Mehta, Y. R. Doenças do trigo e seu controle. São Paulo: Editora Agronômica Ceres Ltda, 1978. 190 p.

5. Prates, L.G.; Fernandes, J.M.C. Avaliando a taxa de expansão de lesões de Bipolaris sorokiniana em trigo. Fitopatologia Brasileira, Brasília, DF, 26: 185-191, 2001.

6. Reis, E. M.; Casa, R. T. Doenças dos cereais de inverno: diagnose, epidemiologia e controle. $2^{\text {a }}$ Ed. revisada e atualizada. Lages: Graphel, 2007. 176p.: il. Color.

7. Sutton, J. C. Predictive value of weather variables in the epidemiology and management of foliar diseases. Fitopatologia Brasileira, Brasília, DF, 13:305-312, 1988.

8. Theisen, G.; Ruedell, J. Tecnologia de aplicação de herbicidas: teoria e prática. Passo Fundo: Aldeia Norte, 2004. 90p.

9. Toledo, J.; Reis, E.M.; Forcelini, C.A. Efeito do substrato na morfologia de conídios de Bipolaris sorokiniana e da densidade de inóculo na intensidade da mancha marrom em cevada. Fitopatologia Brasileira, DF, Brasília, 29:5-10, 2004.

10. Vidal, R. A.; Fleck, N. G. Absorção e translocação de defensivos agrícolas. In: BORGES, L. D. Tecnologia de aplicação de defensivos agrícolas. Passo Fundo: Plantio Direto Eventos, 2007. p.57-70.

11. Zadoks, J. C.; Chang, T. T.; Konzak, C. F. A decimal code for the growth stages of cereals. Weed Research, Oxford, v. 14, p.415-421. 1974. 